PRZEMYSŁAW PLUCIŃSKI*

Uniwersytet im. Adama Mickiewicza w Poznaniu

MAREK NOWAK**

Uniwersytet im. Adama Mickiewicza w Poznaniu

DOI: $10.26485 / \mathrm{PS} / 2017 / 66.3 / 5$

\title{
E PLURIBUS UNUM? ŹRÓDŁA I SPECYFIKA RUCHÓW MIEJSKICH WE WSPÓLCZESNEJ POLSCE
}

\section{Streszczenie}

Artykuł skupia się na dwóch wątkach: wskazaniu i interpretacji źródeł współczesnych miejskich ruchów społecznych (MRS) w Polsce oraz próbie diagnozy zjawiska. Zwracamy uwagę na ideologiczne napięcia, które są obecne w ramach odmiennych nurtów miejskiego aktywizmu, w różnym stopniu poszukujących tożsamości w nawiązaniach do tradycji „prawa do miasta”. Poszukujemy jednocześnie między nimi synergii, swoistej ,,jedności w wielości”, powstającej w warunkach współczesnego środkowoeuropejskiego miasta. Tekst zamyka analiza ilościowa i próba charakterystyki publiczności ruchów miejskich na przykładzie Poznania. Źródłem danych są wyniki exit poll oraz dane Państwowej Komisji Wyborczej.

Słowa kluczowe: prawo do miasta, miejskie ruchy społeczne, ruch neoanarchistyczny, geneza ruchów miejskich

Miejskie ruchy społeczne (MRS) stały się stosunkowo niedawno jednym z najistotniejszych aktorów niezinstytucjonalizowanej, pozaparlamentarnej polityki i sfery publicznej w Polsce. Wzrost aktywności społecznej oraz obywatelskie

* Dr, Instytut Socjologii, Zakład Socjologii Zróżnicowania Społecznego; e-mail: plucin@ amu.edu.pl

** Dr hab. Instytut Socjologii, Zakład Badań Społeczności Lokalnych i Regionalnych; e-mail: marek.nowak@amu.edu.pl 
żądania realnego wpływu na społeczno-polityczne funkcjonowanie wspólnot możemy obserwować $\mathrm{w}$ uproszczeniu od początku nowego millenium ${ }^{1}$. Istotnym impulsem rozwojowym okazały się wówczas liczne konflikty lokalizacyjne, a zatem zdarzenia, dla których scenografię stanowiły obszary poddawane inwestycyjnej presji (tereny zielone, obszary niezabudowane), na których rodził się opór dotychczasowych mieszkańców i użytkowników. Pewna część z tych konfliktów, szczególnie ta, która generowała szersze zakresowo (ogólnomiejskie) niezadowolenie, prowadziła do konstytuowania się miejskich ruchów protestu (często jeszcze zdradzających związki z klasycznym syndromem NIMBY), z czasem ewoluujących w kierunku organizacji i ruchów miejskich, coraz częściej odwołujących się do miasta jako społecznej całości i do narzędzi lokalnej, zinstytucjonalizowanej polityki².

Mniej więcej od lat 2008-2010 wskazane formy oddolnej kooperacji podlegały formalizacji, szeroko korzystając $\mathrm{z}$ formy prawnej organizacji stowarzyszeniowych (powstają wówczas dla przykładu: poznańskie Stowarzyszenie My-Poznaniacy, nieco młodsze Towarzystwo Upiększania Miasta Wrocławia czy łódzka Fundacja Normalne Miasto „Fenomen”), stwarzające podwaliny pod mająca nastąpić niebawem erupcję miejskich ruchów i oddolnych inicjatyw w licznych polskich miastach (od roku 2011 do dziś). W konsekwencji uruchomiony został „marsz przez instytucje” (choćby przez struktury samorządów pomocniczych ustanowionych na podstawie ustawy o samorządzie gminnym z marca $1990 \mathrm{roku})^{3}$, i po częściowo udanych ,przejęciach władzy” (Gorzów Wielkopolski, Poznań) środowiska związane $\mathrm{z}$ aktywistami zyskały szanse wprowadzania zmian.

Warto podkreślić, że jest to zaledwie rys historyczny narodzin polskich MRS, który nie odpowiada na bardziej wnikliwe pytania o genezę późnonowoczesnej środkowoeuropejskiej kontestacji [por. Jacobsson 2015; Nowak 2015]. MRS nie pojawily się na politycznej arenie i w sferze publicznej deus ex machi$n a$. Wskazać można na specyficzną ciągłość, związek z działającymi wcześniej

1 Należy też zauważyć, że proces ten, jakkolwiek sprowadzony tu analitycznie do mniej więcej trzech dekad (czas zdarzeniowy), zakorzeniony jest w szerszym kontekście strukturalno-historycznym. Chodzi przede wszystkim o długi proces wytwarzania miejskich tożsamości i miejskości jako takiej w obrębie postagrarnej i postchłopskiej historyczności. Procesy te, w kategoriach wykraczających poza czas zdarzeniowy, czyli w perspektywie długiego trwania, poddał wnikliwej analizie Paweł Kubicki [2016].

2 Szersze materiały i omówienie tej kwestii patrz: Mergler [2008]; Pluciński [2014]; Urbański [2002].

Wskazanie na dłuższą historię regulacji prawnych (ustaw o fundacjach, stowarzyszeniach i samorządzie gminnym) sugeruje tu przesunięcie w czasie (średnio o 10-15 lat) form oddolnej aktywizacji w stosunku do „odgórnej” ramy prawnej transformacji systemowej. 
ruchami społecznymi, dokładniej zaś na fakt, że określone „miejskie” idee były obecne w myśleniu politycznym ruchów działających w Polsce jeszcze w latach 80. i 90. XX w. bądź to w tradycji uniwersalistycznego ruchu społecznego („Solidarność”), ruchu komitetów obywatelskich, bądź najmłodszym spośród nich - w ruchu (neo)anarchistycznym ${ }^{4}$. Korzenie współczesnej „morfologii” protestu najwyraźniej tkwią w pierwotnej fascynacji zbiorowym działaniem oraz rychłym zaprzeczeniu ideom „zdradzającej samą siebie” „Solidarności”. Już tam, choć zdecydowanie najbardziej jednoznacznie w ostatnim z wymienionych przypadków (neoanarchizm) odnaleźć możemy zaczyn myślenia w kategoriach demokracji miejskiej ${ }^{5}$ czy budżetu partycypacyjnego, którego kształt wydyskutowują mieszkańcy - zatem naczelnych idei współczesnych nam ruchów miejskich.

Choćby z uwagi na sygnalizowaną tu złożoną genezę (mniej lub bardziej radykalną i mniej lub bardziej endogenną) MRS we współczesnej Polsce nie są jednolite, mają zdecydowanie hybrydowy charakter. Różnią się między sobą dość istotnie, przede wszystkim co do podstawowych przestrzeni działania (czyli tego jak definiowane są kluczowe problemy miejskie) oraz tożsamości politycznej czy zaplecza ideologicznego. W tym drugim przypadku idzie przede wszystkim o idee ,prawa do miasta” (the right to the city - RTTC), której interpretacja i sposoby rozumienia wyznaczają jedną z głównych i najbardziej istotnych trajektorii podziałów na mapie ruchów miejskich. Trzeba przy tym zauważyć, że

4 Pojęcie (neo)anarchizmu wprowadzone jest intencjonalnie, by skierować uwagę na kilka istotnych różnic, czy też ,przesunięć”, w obrębie anarchizmu współczesnego w porównaniu z jego tradycyjnymi i historycznymi postaciami. Ruch (neo)anarchistyczny, po pierwsze, jest nie tylko antypaństwowy, ale równie krytyczny wobec kapitalizmu, stąd też występuje nie tylko przeciwko tradycyjnie pojmowanej władzy państwowej i państwowemu monopolowi na przemoc, ale również przeciwko współczesnym postaciom władzy i przemocy ekonomicznej, czego wyrazem było aktywne uczestnictwo ruchów (neo)anarchistycznych w ramach szerokiego ruchu alterglobalistycznego; po drugie zaś w ramach (neo)anarchizmu zaznaczyło się wyraźne - właśnie po załamaniu się alterglobalistycznego ruchu protestu - przesunięcie ku lokalności (glokalizacja), w tym miejskości [por. Pluciński 2016; Pluciński 2017: 96-103], prowadząc do postępującej i coraz wyraźniejszej „urbanizacji anarchizmu”.

5 Samo pojęcie i praktyki przywoływanej tu demokracji miejskiej są szerokie i inkluzywne; ich składnikami są zaś między innymi pojęcie demokracji bezpośredniej i partycypacyjnej (oczywiście nietożsame). To pierwsze, rzadsze jako postulat ruchów miejskich, odsyła do mechanizmów podejmowania decyzji możliwie dalekich od reprezentacyjnego zapośredniczenia (które jednak obecne są w przywoływanym i omawianym w artykule projekcie RSA), to drugie z kolei, zdecydowanie częstsze, do mechanizmów zarówno podejmowania decyzji, jak i uczestnictwa, jednak na ostatnie przenosząc punkt ciężkości. Innymi słowy, postulaty demokracji partycypacyjnej, swej siły poszukujące w praktykach współuczestnictwa i kontroli instytucji demokracji reprezentacyjnej, choćby w ramach sfer publicznych, stanowią jądro miejskiej i partycypacyjnej demokracji. Nie są przy tym nieproblematyczne [por. Partycypacja... 2012; Purcell 2008]. 
idea RTTC - szczególnie w jej sfunkcjonalizowanej postaci - może być traktowana jako swego rodzaju ideologiczny import, wpisujący się, niejako siłą rzeczy, w modernizacyjną ideologię transformacji systemowej, który upowszechnił się w Polsce tylko nieco później niż neoliberalny gestalt switch.

\section{DWA „PRAWA DO MIASTA"?}

Współcześnie RTTC jest główną doktryną praktyczną, do której odwołują się MRS. Ma ona co najmniej dwa wcielenia. Jedno - to bardziej genetyczne - o wyraźnie lewicowej i konfliktowej, w pewnej mierze nawet rewolucyjnej, proweniencji. Wywodzić je możemy z klasycznego dorobku Karola Marksa oraz niedocenianej długo w przestrzeni badań nad miastem myśli Fryderyka Engelsa [por. Merrifield 2002; Pluciński 2012]. Do nich to nawiązywał, ogłaszając tezy swojej filozofii społecznej jeszcze w latach sześćdziesiątych minionego stulecia, ojciec ideowy sporej części ruchów miejskich - Henri Lefebvre [2012]. Drugie, niewiele mające wspólnego z antysystemowością tego pierwszego, wynika z ewolucji myślenia o mieście, a precyzyjniej: wiąże się z „uprzestrzennieniem” indywidualnej podmiotowości typu obywatelskiego i pojawianiem się żądań uwzględniania interesów dotychczas niemych użytkowników dóbr wspólnych.

Z czasem, przede wszystkim z uwagi na rozmaitość wspomnianych użytkowników, idea RTTC sta(wa)ła się coraz bardziej otwarta interpretacyjnie. Przestała być jedynie domeną buntu, mówiąc językiem Webera, „negatywnie uprzywilejowanych". Stawała się zaś bardziej credo zuniwersalizowanej i zbiorowej podmiotowości. Proces ten ma wiele wspólnego z metaforycznie ujętymi zjawiskami dyfuzji i interferencji - gdy pewne idee trafiają na podatny grunt i wydają się skuteczniej niż inne ideologie sterujące ramować społeczny dyskurs. Ideologia RTTC w tym wydaniu ma charakter przede wszystkim reformistyczny, stwarza podstawy dla strategii mediacyjnych w stosunku do innych ideologii politycznych oraz do „hakowania systemu” [Nawratek 2008], a zatem pozbawionego ideologicznego oporu angażowania się w zinstytucjonalizowane struktury władzy lokalnej, by je zmieniać od środka ${ }^{6}$.

Idea RTTC została w związku z tym poddana daleko idącej reinterpretacji. Dziś da się o niej mówić jako o „pustym znaczącym”, co uprawomocnia „wy-

${ }_{6}$ Co interesujące, obydwie perspektywy - podchodząc do nich relacyjnie - są od siebie częściowo współzależne, ale pozostają ze sobą w związku, szczególnie w kontekście uogólnionych procesów demokratyzacji i wydarzeń tworzących biografie ludzi pokoleniowo związanych z przełomem lat 1989-1990. 
pominanie" genezy polityczno-ideologicznego zróżnicowania [Harvey 2012: 186-187]. Uprawomocnia również poszukiwania zjawisk nakładania się owej „zewnętrznej” idei na uwarunkowania historycznego „tu i teraz”, w którym można poszukiwać różnych biografii i rodowodów ideologicznych, różnych klasowych korzeni i statusów społecznych w ramach ,jedności poprzez wielość" (e pluribus unum). Zakłada potrzebę dystansu wobec pierwotnego, marksistowskiego źródła RTTC oraz nowego, aideologicznego języka - unikając jednocześnie literalnych nawiązań do tradycyjnych kategorii prawicy i lewicy (z którymi to, jeśliby myśleć normatywnie, MRS „powinny” się domyślnie utożsamić). W podobny sposób budowany konstrukt ideologiczny nieprzypadkowo szczególnie wyraźnie formułuje część aktywistów związanych ze skrzydłem mieszczańskim [Pobłocki 2014: 94-96], którego społeczne usytuowanie jest centrowe.

\section{AKTORZY ZBIOROWI W KONTEKŚCIE MIASTA ŚRODKOWOEUROPEJSKIEGO}

Interesuje nas między innymi ogólna charakterystyka zróżnicowania w obrębie pola miejskiego aktywizmu w Polsce. Zbiór podmiotów, które można tutaj opisywać, jest stosunkowo szeroki. Należą do niego przede wszystkim:

(1) z jednej strony ruchy (neo)anarchistyczne, na przykład poszczególne sekcje Federacji Anarchistycznej, spośród których najbardziej aktywne wydają się być środowiska poznańskie, warszawskie i krakowskie;

(2) ruchy lokatorskie, mające charakter ogólnopolski, choć znów można tu wymienić podmioty szczególnie aktywne, takie jak Wielkopolskie Stowarzyszenie Lokatorów, Warszawskie Stowarzyszenie Lokatorów czy również stołeczny Komitet Obrony Lokatorów - konstytuujące socjalnie zorientowane skrzydło MRS;

(3) z drugiej strony - najsilniejsze i częściowo utożsamiane z całością zjawiska ruchów miejskich tzw. ruchy mieszczańskie (niekiedy określane mianem „miejskich ruchów klasy średniej”) oraz

7 Proponowana typizacja ma charakter przybliżenia, w tym sensie, że na przykład zarówno ruchy lokatorskie, jak i „mieszczańskie” mogą przyjmować formalnoprawną postać organizacji trzeciego sektora z wszystkimi zaletami, ale i zagrożeniami. Ponadto wyróżnione tu rozłącznie typy ruchów częstokroć nie przyjmują form czystych, nierzadko też wchodząc ze sobą w rozmaite sojusze organizacyjne i taktyczne.

Warto też wspomnieć, że przywołując przykłady konkretnych ruchów i inicjatyw, odwołujemy się do tych najbardziej oczywistych, dobrze rozpoznanych w sferze publicznej. Nie sposób bowiem w artykule odnieść się do kilkuset rozmaitych i działających w skali kraju miejskich ruchów, stowarzyszeń i inicjatyw. 
(4) bardzo liczne, ale słabiej zinstytucjonalizowane inicjatywy lokalne organizujące się np. wokół samorządów pomocniczych, parafii, szkół, podwórek, wspólnot sąsiedzkich etc.;

(5) organizacje tzw. trzeciego sektora, zinstytucjonalizowane i sformalizowane, działające w polu miejskich polityk, obciążone jednak ryzykiem quango-izacji ${ }^{8}$. Wreszcie są to również

(6) partie polityczne ${ }^{9}$, a więc aktorzy działający coraz śmielej w polu ruchów społecznych, w tym miejskich, dokonujące też w jego ramach coraz wyraźniejszych ,przechwyceń”.

To, czy można na tym heterogenicznym gruncie mówić o „wielości w jedności" (e pluribus unum), powinno być przedmiotem weryfikacji empirycznej. Istotne wydaje się wskazanie na specyfikę fenomenu MRS, by - przynajmniej na poziomie hipotezy - dowodzić, że nietożsame politycznie rodowody mogą prowadzić do podobieństw, których źródła wynikają z nacisku środowiska - w środkowoeuropejskim kontekście - postsocjalistycznego miasta. Jak rozumiemy ów środkowoeuropejski kontekst?

Mówiąc o specyfice miasta środkowoeuropejskiego, należy uwzględnić dwa fakty: kontekst skali - globalnej, narodowej i lokalnej [Smith 2010: 175-205; Mergler, Pobłocki 2010: 6-14] - oraz istotną zmianę ideologiczną prowadzącą do globalnej zmiany kierunku polityk gospodarczych i społecznych, która dokonała się na przełomie lat 80 i 90. ubiegłego stulecia, a była związana z procesem upadku realnego socjalizmu i tryumfem radykalnej wersji kapitalizmu, niekiedy określanego mianem „neoliberalizacji” [Brenner, Peck, Theodore 2010; Brenner, Theodore 2012], szczególnie w kontekście „wędrówki” kapitału poszukującego w ośrodkach miejskich przestrzeni akumulacji [Harvey 2012].

Owo globalne przesunięcie oddziaływało oczywiście silnie na konteksty narodowe i lokalne, w ramach których miasto jest definiowane jako przestrzeń koncentracji nadwyżek kapitałowych i ,,maszynka do robienia pieniędzy”. Specyficzny wariant tego procesu miał miejsce w krajach wkraczających dwie i pół dekady wcześniej na ścieżkę transformacji systemowej w duchu przywołanego już gestalt switch [Aslund 2010; Kowalik 2009]. Prowadził do poszukiwań ścieżki wzrostu poprzez radykalne polityki deregulacji i prywatyzacji oraz właściwe

Jako jeden z nielicznych polskich socjologów problem ten stawia Rafał Drozdowski [2011].

9 Najwyraźniejszym przykładem jest w Polsce Partia Zielonych; warto też wspomnieć o stosunkowo niedawno utworzonej partii Razem, która wyraźnie odwołuje się do oddolnego aktywizmu oraz tradycji ruchów społecznych, kładąc nacisk na horyzontalną strukturę organizacyjną. 
dla systemu postfordowskiego „uelastycznienie systemu”10, na poziomie miast wprowadzając menedżerskie zarządzanie dobrami publicznymi jak przedsiębiorstwem (na przykład tzw. new public management), połączone wreszcie ze specyficzną, „resocjalizacją” i potrzebą wytworzenia „,nowego człowieka” [Dunn 2008] - liberalnie i indywidualistycznie nastawionej jednostki, i jej ,prywatyzmu obywatelskiego" [Ost 2005; Jacobsson 2013].

Owa makrostrukturalna zmiana wzmagała czysto lokalne procesy - odsłaniając tym samym napięcia strukturalne środkowoeuropejskiego miasta przełomu wieków: potęgowała chaos przestrzenny (brak zdecydowanych regulacji dotyczących warunków zabudowy oraz słabość instytucji je egzekwujących), generowała liczne konflikty reprywatyzacyjne (fetysz własności prywatnej), wreszcie też - ze względu na politykę deregulacji i cięć wydatków społecznych - skutkowała postępującą deprywacją zaspokojenia społecznych potrzeb (polityka mieszkaniowa, opiekuńcza czy oświatowa i edukacyjna).

Ruchy miejskie w Polsce nie są na tyle uniwersalistyczne (czy w ogóle mogą takie być?), by podjąć jako wyzwanie całość strukturalnego kontekstu limitującego szanse ,alternatywnej modernizacji”. Stąd też w ich ramach mamy do czynienia $\mathrm{z}$ w pewnej mierze funkcjonalnym podziałem pracy - każde ze skrzydeł podejmuje problemy w mniemaniu swoich aktywistów kluczowe, konstytuując tytułową, ,jedność w wielości”.

\section{E PLURIBUS UNUM?}

Kluczem do odpowiedzi na pytania o fenomen „różnicy w jednorodności” miejskiego aktywizmu docelowo są oczywiście badania empiryczne; ich punktem wyjścia powinny być przy tym badania nad „miejską ideologią”, na przykład na podstawie analizy treści przekazów formułowanych przez ruchy.

Korzystając zatem ze wzmiankowanej różnicy ideologicznej w odczytywaniu idei RTTC, zestawimy ze sobą dwa główne typy samoorganizacji, które istotnie dzieli poziom radykalizmu skierowanego wobec systemu. Interesować nas jednak będzie jedynie określony wycinek szerszej całości, a precyzyjnie: problem genezy (1) dominujących w polu MRS ruchów klasy średniej oraz (2) ruchów proweniencji neoanarchistycznej, silniej związanych z ruchem lokatorskim.

10 Z perspektywy teoretycznej (głównie, choć niewyłącznie, w ujęciu teorii konfliktowych) część tych procesów - odwołując się do autorów, takich jak D. Harvey, N. Smith, B. Jessop czy E. Soja - omawia Mateusz Błaszczyk [2013]. 
Relacje pomiędzy wskazanymi podmiotami mają charakter dialektyczny. Pozostają w sytuacji napięcia dotyczącego interpretacji ideologicznych definicji miejskich problemów, strategii działania. $Z$ jednej strony nie szczędzą sobie wzajemnych krytyk, z drugiej potrafią też kooperować, szczególnie w przypadku powoływanych do życia ad hoc sojuszy ${ }^{11}$. W tej zaś mierze dopełniają się wzajemnie, odwołując się do rozmaitego rozumienia idei dobra publicznego jako dobra wspólnego, to ostatnie jednak sytuując w centrum zainteresowania.

Dokonamy w tym momencie lekkiego rekursu, z jednej strony nawiązując do lokalnych/miejskich wątków obecnych w dziedzictwie „Solidarności”, z drugiej te same fascynacje, ale inaczej rozstrzygnięte, odnajdując w ruchach radykalnych, rozczarowanych „samoograniczającą się rewolucją”. W pewnej mierze to napięcie jest obecne do dziś - z jednej strony mamy zatem MRS, które skupiają się na Realpolitik, na walce o to, co możliwe; z drugiej obecni są ci, którzy w imię realnej zmiany - przywołując kontrkulturowe wykrzyknienie - ,żądają niemożliwego"

\section{„ARCHEOLOGIE MRS" - RUCH KOMITETÓW OBYWATELSKICH}

Interesują nas dwa wątki związane z „Solidarnością” - ożywienie w jej ramach idei komitetów obywatelskich, których tradycja jest dłuższa niż opozycja demokratyczna końca XX w. [por. Nowak 2007; Słodkowska 2014, Wstęp] oraz specyfika demokratyzacji w warunkach mobilizacji „przedpolitycznej”, a zatem mobilizacji w pewnym zakresie abstrahującej od klasycznych podziałów na lewicę, prawicę i centrum. Co istotne, nie twierdzimy, że „Solidarność” była ruchem miejskim, co zapewne należałoby uznać za prezentyzm, czy nawet protomiejskim. Jednak jako matkę buntu licznych kontrruchow (w tym RSA) oraz kolebkę nowoczesnego społecznego aktywizmu w Polsce warto wziąć ją w jakimś stopniu pod uwagę. Jest ona bowiem przestrzenią restytucji kluczowych wspólnotowych doświadczeń: samoorganizacji, zbiorowego decydowania, niemonologowego organizowania dyskursu etc.

Przejawów samoorganizacji w konwencji komitetów obywatelskich można przywoływać wiele. Odwołując się już bezpośrednio do ruchu polskich komitetów z lat 1989-1992, mamy na myśli istnienie i intensywną pracę dziesiątek - mniej lub bardziej sformalizowanych, lepiej lub gorzej zorganizowanych - oddolnie

11 Dobrym tego przykładem jest kwestia lokatorska w Poznaniu, szczególnie zaś zawiązanie szerokiego aliansu ruchów i inicjatyw społecznych wokół protestów przeciw praktykom tzw. czyszczenia kamienic czy protestów wobec „kontenerów socjalnych”. 
koordynowanych struktur, których działalność była celowa, zorientowana na realizację konkretnego zadania (wygrania wyborów z 4 czerwca 1989), które poprzez swoją oczywistość niwelowało niekiedy radykalne różnice poglądów i było podstawą szerokiej horyzontalnej współpracy.

Zapewne najlepiej oddaje sens tych form aktywności pojęcie ,pospolitego ruszenia”, w ramach którego „wszyscy” się znają i ,wszystko” da się przedyskutować. Przy czym owo „ruszenie” oznacza formę działania (w opozycji również do form biernego oporu), które może mieć zwrot zarówno prospektywny (by coś wywalczyć), jak i może być zorientowane na obronę określonych wartości (np. społecznego spokoju, ciągłości działania instytucji czy usług publicznych). By oddać społeczną specyfikę tej formy działania, warto posłużyć się przykładem wskazywanego już ruchu z przełomu lat 80. i 90. XX w. Inka Skłodkowska opisuje specyfikę organizacji komitetów obywatelskich jako „szeroką koalicję - reprezentację głównych sił opozycyjnych. Wzajemne usytuowanie tych sił oraz rodzaj kontaktów między nimi determinował sposób powoływania i organizacji Komitetu Obywatelskiego oraz sztabu wyborczego w danym regionie" [Słodkowska 2010: 47].

Organizacja ta, powoływana z reguły ad hoc, miała charakter terytorialny, najczęściej związany z centralnym na danym obszarze ośrodkiem miejskim, i sieciowy: opierała się na dobrowolnej kooperacji podmiotów zbiorowych i osób prywatnych, które łączył uogólniony cel i specyfika zbiorowej woli, dającej podstawy do strategicznych, często nieformalnych porozumień.

Ich żywotność, tak jak w przypadku wyborów do tzw. sejmu kontraktowego, była zazwyczaj ograniczona, a formy działania stały się później podstawą formalizacji, która przekraczała granice porozumienia uruchamiającego zbiorowe współdziałanie (ruch stracił szybko swoją integralność na korzyść ostrej konkurencji). Był to zatem fenomen społeczny o bardzo szczególnym charakterze, co przywodzi na myśl formy mobilizacji, które 25 lat później towarzyszyły kluczowym dla tożsamości mieszczańskich ruchów miejskich w Polsce wyborom z 2010 i 2014 roku, również w kontekście częściowego sukcesu prowadzące do podziałów i uruchamiające konflikty i autonomiczne procesy grupotwórcze.

Wskazane powyżej analogie sugerują zatem określoną specyfikę samoorganizacji, wytwarzającą kulturowe i społeczne know-how, czy też może „działaniowe dziedzictwo", jako zasób, z którego, w różnych uwarunkowaniach sytuacyjnych i w różnym ideologicznym entourage'u, korzystać mogą rozmaici aktorzy społeczni. 


\section{„ARCHEOLOGIE MRS” - PONOWNE NARODZINY POLSKIEGO ANARCHIZMU}

Jako protomiejskie, traktować możemy część ruchów (neo)anarchistycznych działających również w latach 80 . w ramach szerszego frontu politycznych ruchów protestu. Kluczowym aktorem zbiorowym było tu trójmiejskie ugrupowanie nieformalne Ruch Społeczeństwa Alternatywnego (RSA). Dotychczasowe nieliczne narracje poświęcone polskim MRS w zasadzie ten wątek ignorują zaś tradycja (neo)anarchistyczna w obrębie pola ruchów miejskich jest traktowana jako ,złe narodziny" [Pluciński 2014: 147-148; Pluciński 2016]. Ważnym doświadczeniem dla późniejszych aktywistów RSA, choćby dla Janusza P. Waluszki, związanego w młodości z kręgami skupionymi wokół kapelana „Solidarności” z gdańskiej parafii św. Brygidy, księdza Henryka Jankowskiego, było doświadczenie jej pierwszych ideałów, szczególnie zaś pierwotny horyzontalizm i rys syndykalistyczny w jej obrębie.

Trójmiejski RSA ukonstytuował się jako grupa nieformalna jeszcze w roku 1983. Organem wydawniczym RSA było nieregularne czasopismo ulotne Homek. To właśnie na jego łamach na przełomie lat 80. i 90. opublikowano dwa kluczowe „miejskie manifesty” RSA. Od samego początku działalności, w pewnej mierze intuicyjnie, członkowie RSA położyli nacisk w działaniu na skalę lokalną, otwarcie poszukując szans na zaistnienie demokracji bezpośredniej w ramach określonej, częściowo historycznie kształtowanej przestrzenności dzielnic. RSA otwarcie podejmował kwestię politycznej organizacji miasta, które „powinno być niezależne od jakiejkolwiek władzy centralnej” [Homek: 195], nacisk kładąc na autonomię i możliwie najdalej posuniętą autarkię. Słabiej opracowany był wątek organizacji ponadlokalnej - w tym zakresie główną propozycję stanowiły odwołania do federalizmu [Homek: 195-196].

Miasto miałoby być zarządzane przez mieszkańców, nie zaś przez reprezentacyjne elity w oparciu o idee demokracji bezpośredniej. Podstawową instytucję stanowiłoby zgromadzenie mieszkańców (to tu miało dochodzić do procesu politycznego „kształtowania woli”), dopełnione przez samorządy osiedlowe. Te ostatnie z kolei miały brać na siebie obowiązki administracyjne oraz - po części - doradcze, w zależności od bezpośredniego zainteresowania i potrzeb wyrażanych przez mieszkańców osiedli.

Podstawą fiskalną tak określonego ładu miejskiej demokracji bezpośredniej powinny być składki (celowo unikano nazwy ,podatek”, maskując tym samym ich fiskalny co do funkcji charakter), określane proporcjonalnie do dochodu mieszkańca, oraz obowiązkowe opodatkowanie działających w mieście przedsiębiorstw 
(w ich przypadku pojęcie opodatkowania wprowadzone było już otwarcie). Zgromadzona pula dochodów, składająca się na-jak dziś moglibyśmy to ująć - budżet obywatelski, miałaby służyć przede wszystkim finansowaniu usług komunalnych.

Dlaczego wątek protomiejskiego charakteru ruchu RSA jest tak istotny? $\mathrm{Z}$ dwóch powodów. Dominujące dziś narracje dotyczące MRS w zasadzie ignorują tak rozumianą historię polskich MRS, marginalizując przy tym ruchy miejskie o anarchistycznej proweniencji ${ }^{12}$. Działalność RSA stanowi przy tym punkt odniesienia dla licznych, rozwijających swoją działalność już w latach 90. ubiegłego wieku ugrupowań (neo)anarchistycznych. Doszło wówczas przecież do ,eksplozji" pierwszej fali skłotingu oraz licznych inicjatyw związanych z odzyskiwaniem miejskiej przestrzeni. To również środowiska neoanarchistyczne poczęły wysuwać postulaty socjalne, antycypując nabrzmiewające problemy strukturalne: wycofywanie się władzy z roli dostarczyciela dóbr i usług konsumpcji zbiorowej. W programie poznańskiego Porozumienia Społecznego „Poznań Miasto Dla Ludzi” możemy przeczytać: „Poznań miastem nie dla eksmisji na bruk ludzi biednych [...], nie dla wyprzedaży i przejmowania przez prywatnych «właścicieli» mieszkań komunalnych [...], nie dla polityki władz lokalnych, która preferuje biznes i inwestycje nie uzgadniane z mieszkańcami [...]" [Antonów 2004: 340].

To również ze strony środowisk neoanarchistycznych zgłaszane były pierwsze postulaty budżetowania obywatelskiego [Górski 2007], które to jeszcze dziesięć lat temu były traktowane jako niebezpieczne i radykalne. Kilka lat później, choć w mocno zmodyfikowanej i po części plebiscytowej formule, weszły do słownika i praktyki politycznej lokalnych władz. W chwili obecnej budżetowanie obywatelskie jest elementem polityki kilkudziesięciu miast.

Wreszcie, to również ruchy (neo)anarchistyczne poczęły (re)animować polski ruch lokatorski. Krakowscy działacze Federacji Anarchistycznej jeszcze w latach 90. protestowali przeciwko podwyżkom czynszów czy eksmisjom. Niedługo później identyczne działania zaczęli podejmować neoanarchiści poznańscy [Antonów 2004: 340]. Działania zinstytucjonalizowane najszybciej podjęli działacze warszawscy, choćby w ramach kampanii „Mieszkanie prawem - nie towarem" oraz powstałego w jej efekcie Warszawskiego Stowarzyszenia Lokatorów [Ciszewski 2008/2009; Warszawskie Stowarzyszenie Lokatorów... 2008/2009]. Obecnie duża część wpływowych ruchów i organizacji lokatorskich cały czas pozostaje w synergicznym aliansie z ruchem skłoterskim i neoanarchistycznym [Piotrowski, Polanska 2015]. Ma to miejsce choćby w Krakowie, Poznaniu czy Warszawie [Warszawskie Stowarzyszenie Lokatorów 2008-2009].

12 Lech Mergler otwarcie umieszcza je poza obszarem MRS [Mergler 2014: 90]. 


\section{ANARCHIŚCI I MIESZCZANIE}

Zatem w pewnym sensie przeciwstawienie „pospolitego ruszenia” Polaków końca lat 80. XX w. i „młodzieżowego” (wówczas) ruchu neoanarchistycznego może wydawać się nieporozumieniem. Patrząc jednak z innej strony, jest to klasyczny problem figury synekdochy, kiedy zjawiska o znacznie szerszym zakresie nazywa się, odnosząc do stosunkowo wąskich, konkretnych doświadczeń. Ruch Społeczeństwa Alternatywnego może być dla refleksji na temat oddolnej samorządności miejskiej emblematyczny, z drugiej jednak strony jego oddziaływanie długo miało raczej lokalny charakter. Istotna jest zatem nie tyle dyskusja o tym, który z ruchów był pierwszy, czy komu przypisać „, archetypiczność”, ile podkreślenie fenomenu konwergencji wyodrębniających się nurtów obywatelskiego aktywizmu.

Jak założyliśmy - dla nurtu, który umownie nazywamy mieszczańskim - nie ma już dziś kontekstu jednej ideologii sterującej ${ }^{13}$. Nie sposób mówić też o ciągłości pokoleniowej. Paradoksalnie można wręcz sugerować, że współczesne formy „samograniczającej się kontestacji” ruchów miejskich skierowane są przeciw pokoleniu, które publiczne szlify zdobywało właśnie na przełomie lat 80 . i 90. XX w., później zaś zasiliło potransformacyjne elity polityczne. Innymi słowy, jest to bunt przeciwko środowiskom odpowiedzialnym za wyczerpująca się formułę „monologowej” modernizacji. Na poziomie metafory da się tu zatem przywołać Freudowską figurę ojcobójstwa. Z jednej strony ruchy mieszczańskie, nie podkopując samych fundamentów transformacyjnej zmiany, obwieszczają fakt wyczerpania neoliberalnej ideologii sterującej, proponując przy tym utrzymanie fundamentów zastanego ładu, kurs modernizacyjny w oparciu o inny zestaw reguł.

Ruch neoanarchistyczny z tego punktu widzenia w zdecydowanie większym stopniu miałby charakter względnie stałego społecznego kontrapunktu dla polityk miejskich, lokując się konsekwentnie poza mechanizmami „krążenia elit”14. Ruch ten - jeśli mielibyśmy sprowadzić go do bon motu - odrzuca całość, nie godząc się na część.

Ruchy mieszczańskie z kolei, jak pokazuje przykład poznański, choć analogii można poszukiwać również we Wrocławiu czy Warszawie, rodzą się nie tyle jako głos przeciwko systemowi czy formom zoligarchizowanej demokracji przedstawicielskiej, ile jako konsekwencja stricte lokalnych i z tej perspektywy partykularnych protestów lokalizacyjnych [Frączak 2010; Matczak 1996; Mergler 2008].

$13 \mathrm{~W}$ tradycyjnym pojmowaniu takiego aparatu ideologii sterujących nowoczesności - liberalizmu, konserwatyzmu i socjalizmu.

14 Jakkolwiek na przykład w Poznaniu odegrał szczególną rolę i od czasu do czasu otwarcie angażował się w konflikty polityczne po jednej z jego stron. 
Rodzą się zatem z działania zagnieżdżonego w systemie, którego efektem ma być jego korekta, nie zaś fundamentalna zmiana. Ruchy mieszczańskie - analogicznie sprowadzając rzecz do kolejnego bon motu - odrzucając część, godzą się na całość.

\section{ANALIZA DOKUMENTÓW}

Przykładem „mieszczańskiego” myślenia o proteście i o podmiotowości może być Anty-bezradnik przestrzenny [Mergler, Pobłocki, Wudarski 2013], który stanowi zapis wieloletnich doświadczeń współudziału w polityce miejskiej z pozycji obywatelskiego nadzoru (ang. watchdog). To właśnie w Anty-bezradniku... mamy do czynienia z myśleniem wyraźnie reformistycznym, którego wyrazem jest idea „narracji konkretnych", poszukująca skutecznego protestu społecznego w jego oderwaniu od klasycznych konceptów ,ideologicznych” (anarchizm, marksizm, lewica vs. prawica) i odnajdująca go w doświadczeniu konkretnych miejsc.

Tym zatem, co warto powtórzyć w odniesieniu do mieszczańskich ruchów miejskich, jest wskazanie na kontekst konkretnego protestu i konkretnego historycznego działania (niezgody na coś w konkretnym miejscu i konkretnym momencie), który inaczej osadza specyfikę działania w relacji do systemu sprawowania władzy. Ruch neoanarchistyczny jest z definicji antysystemowy ${ }^{15}$, opozycyjność ruchów mieszczańskich rodziła się w oparciu o częściową akceptację reguł gry ${ }^{16}$. Ta szczególna sytuacja konwergencji oraz jednoczesnego „niedopasowania” prowadziła - odwołamy się znowu do doświadczeń poznańskich - z jednej strony do strategicznych aliansów ad hoc (na przykład w części kwestii lokatorskich), z drugiej zaś do niemal otwartego konfliktu między nimi, gdy przedstawiciele środowisk mieszczańskich coraz wyraźniej rozpoczynali „marsz przez instytucje” (weszli w szeregi lokalnej władzy, rady miasta, stawali się urzędnikami).

Przywołując inne dokumenty wypracowane w ramach MRS, zauważymy, że dobrą ilustracją napięcia pomiędzy radykalizmem a reformizmem może być tzw. 9 tez miejskich z 2011 roku [por. Tezy o mieście 2011]. Ich treść otwiera

15 Czy był to „realny socjalizm”, czy jest „realny kapitalizm”, inaczej tylko rozkłada akcenty: z pozycji antypaństwowych przechodząc na antykapitalistyczne?

16 Ta odmienna geneza, przywodząca na myśl ideologię komitetów obywatelskich prowadzi do innego usytuowania ruchu społecznego na osi radykalizm versus reformizm. W jednym przypadku stawia (neo)anarchistów w pozycji nieusuwalnej kontestacji, w drugim - „mieszczan” w pozycji formułujących roszczenia aktywistów, przy czym owe roszczenie obejmuje żądanie uczestnictwa we władzy i w rezultacie wymianę elit, w oparciu o legalną, demokratyczną formułę. Wykluczyć nie możemy przy tym możliwej, po Michelsowsku pojmowanej „oligarchizacji” nowych, wywodzących się ze środowisk aktywistycznych, elit władzy. 
zdanie o tym, że „mieszkańcy mają niezbywalne prawo do miasta”, co oznacza żądanie udziału w lokalnych rządach, nie dotyczy zatem jedynie zaspokojenia określonego rodzaju potrzeb w większym bądź negocjowanym zakresie. Jest to wola bezpośredniego uczestnictwa, które kwestionuje założenie wąskiej specjalizacji czy też przejawów technokracji. Drugi punkt doprecyzowuje założenia tego modelu władzy w oparciu o koncepcję budżetu partycypacyjnego, który polega na „tworzeniu przez mieszkańców całego budżetu miasta”. Z postulatem o podobnym brzmieniu sąsiaduje jednak żądanie „sprawiedliwości społecznej”. To właśnie ono wzbudzało najszerszy sprzeciw, zaś część zgromadzonych w ramach I Kongresu Ruchów Miejskich środowisk odrzuciło uzupełnianie postulatów „podmiotowościowych” o postulaty redystrybucyjne. Na przykład stołeczne stowarzyszenie SISKOM nie przyjęło „tez” z uwagi na ich ideologiczny, nazbyt - zdaniem jego reprezentantów - lewicowy charakter [Pobłocki 2014].

Podmiotowość ruchów miejskich wyrasta zatem z dwóch korzeni, którym można przypisać przeciwne ideologiczne potencjały. Dwa pierwsze punkty dadzą się wpisać zarówno w neoanarchistyczny postulat (autonomistycznego) samorządzenia, jak i współczesny wariant republikańskiego konserwatyzmu. $\mathrm{W}$ połączeniu z trzecim postulatem (najogólniej dotyczącym redystrybucji) czynią tę ideologię swoista, opartą na samoograniczeniu i „cnocie”, w pewnym zakresie skazując ją na wewnętrzne rozdarcie. To w tym miejscu da się zarejestrować napięcie, które ilustruje opisywany dylemat radykalizmu i reformizmu ruchów miejskich.

Wreszcie, specyfikę tego szczególnego zderzenia obrazują również uwagi do dokumentu przygotowywanego przez ministerstwo rozwoju regionalnego zatytułowanego Krajowa Polityka Miejska, w którego tworzenie mocno zaangażowani byli miejscy aktywiści [Nowak 2015]. Wzmiankowany radykalizm obecny jest tutaj w części dokumentu poświęconej polityce mieszkaniowej. Aktywiści postulują radykalną zmianę polityki mieszkaniowej, której leitmotivem jest powszechna dostępność w oparciu o najem, w opozycji do traktowania mieszkania jako towaru.

Nie wchodząc w szczegóły dokumentu, należy zauważyć, że obecna jest w nim wizja miasta, które wyraźnie przedefiniowuje hierarchie rozwojowe, koncentrując się na kwestiach jakości życia i redystrybucji zasobów, wyłączając pewne pola z obszaru regulacji rynkowej. Drogą do tego politycznego celu ma być forma partycypacji, a zatem oddolne mechanizmy decydowania i zaangażowanie samych mieszkańców.

Nie jest to wizja odległa od oświeceniowego progresywizmu, a zatem w pewnym zakresie antyliberalna. Paradoksalnie może mieć ona zarówno proweniencję 
skrajnie lewicową, czy autonomistyczna, jak również wpisywać się w ideologię „ucywilizowania” wcześniej skomodyfikowanych relacji społecznych (za pomocą polityki władzy municypalnej) czy „europeizacji” w oparciu o modele wspierania mieszkalnictwa realizowane „gdzie indziej” - we Francji czy we wschodnich Niemczech ${ }^{17}$.

Ponieważ postulaty są daleko idące (zakładają zmiany odznaczające się różnym stopniem radykalizmu), przyjmuje się potrzebę reorientacji świadomościowej mieszkańców miast, najogólniej w kierunku jakości życia i ,zrównoważenia rozwoju".

Dostrzegając (przynajmniej) dualną specyfikę miejskich ruchów społecznych - która, naszym zdaniem, wymaga dalszych badań - należy też przyjrzeć się publiczności tego przekazu, co może pozwolić oszacować skalę akceptacji postulatów ruchów miejskich. Spróbujemy to zrobić na przykładzie Poznania: na podstawie exit poll i wyników ostatnich wyborów samorządowych i wyboru prezydenta miasta.

\section{PRÓBA CHARAKTERYSTYKI PUBLICZNOŚCI RUCHÓW MIEJSKICH NA PRZYKLADZIE POZNANIA: WNIOSKI Z BADANIA EXIT POLL (WYBORY SAMORZĄDOWE 2014)}

Warto podkreślić, że w przypadku Poznania w 2014 roku mieliśmy do czynienia z wyborami, które stanowiły swego rodzaju publiczną ocenę długoletnich rządów Ryszarda Grobelnego: prezydenta, który na przestrzeni lat zdobył sobie mocna, niezależną pozycję polityczną. Pozycję polityka technokraty sprawnie rozgrywającego lokalny konflikt polityczny, który był w stanie zbudować stabilne relacje w otoczeniu bardzo silnej, co jest specyfiką Poznania, Platformy Obywatelskiej.

W poznańskich wyborach starło się kilku kandydatów, spośród których wielu miało doświadczenie albo współuczestnictwa, albo też współpracy z matecznikiem polskich ruchów mieszczańskich - Stowarzyszeniem My-Poznaniacy. Chodzi tu zarówno o kandydatów społecznych: Annę Wachowską-Kucharską i Macieja Wudarskiego (były członek My-Poznaniacy i kandydat stowarzyszenia „Prawo do Miasta”), ale i reprezentantów dużych partii politycznych: Tadeusza Dziubę (PiS) i Jacka Jaśkowiaka (obaj byli członkami Stowarzyszenia My-Poznaniacy, zaś Jaśkowiak był kandydatem na prezydenta miasta $\mathrm{z}$ jego ramienia

17 W dokumentach ruchów pojawiają się nawiązania do dokumentów UE, np. tzw. Karty Lipskiej. 
w roku 2010, a w roku 2014 kandydatem PO). Do „miejskiej” retoryki bardzo sprawnie odwoływał się też kandydat SLD, Tomasz Lewandowski.

Zmiana, która dokonała się w wyniku wyborów (wygrał je właśnie kandydat PO, Jacek Jaśkowiak), mogłaby zatem nie wydawać się radykalnym zerwaniem, wybory wygrał wszak reprezentant środowiska współrządzącego Poznaniem od lat. Z drugiej jednak strony to przecież były kandydat rodzących się kilka lat wcześniej mieszczańskich ruchów miejskich. Jego zwycięstwo to zatem zwycięstwo osoby tożsamościowo powiązanej z ruchami miejskimi (ale nie samego ruchu), która jednocześnie zaczęła testować ścieżkę wpływu politycznego poprzez istniejące struktury partii politycznych, a zatem w opozycji do strategii autonomii realizowanej przez poznańskie ruchy miejskie. Jego zwycięstwo stało się możliwe w drugiej turze wyborów, gdy partyjnego kandydata poparły zarówno poznańska lewica (formalnie SLD), jak i ruchy miejskie, podpisując porozumienie programowe.

Przyjrzyjmy się wynikom exit poll. Nie mamy tu bynajmniej do czynienia ze zbiorowościami demograficznie homogenicznymi: elektoraty poszczególnych kandydatów nie różnią się istotnie od siebie, jeśli chodzi o wiek czy wykształcenie. Jak wynika z danych, grupa zwolenników kandydatów ruchów miejskich (A. Wachowska, M. Wudarski) była nieznacznie lepiej wykształcona zarówno w stosunku do elektoratu kandydata SLD (T. Lewandowski), PO (J. Jaśkowiak), jak i PiS-u (T. Dziuba); była też tylko nieznacznie młodsza, choć nie tak młoda, jak elektorat zwolenników Nowej Prawicy (Z. Kopacz). Różnice znacznie lepiej widać na tle kandydatów wyraźnie konserwatywnych (kandydat PiS oraz dotychczasowy prezydent). Klucz do zrozumienia poznańskiej specyfiki może zatem leżeć w logice ewolucji świadomości wyborców (ideologie miejskie współwytwarzające lokalną sferę publiczną i prowadzące do uruchomienia społecznych „procesów uczenia się"), nie zaś prostej ekstrapolacji konfliktu pokoleniowego czy różnic potencjału edukacyjnego decydujących o preferencjach wyborczych. Mogłaby na to wskazywać analiza przepływu elektoratów w drugiej turze wyborów.

TABELA 1. Wyniki I i II tury wyborów prezydenta miasta w Poznaniu oraz wskaźnik wykształcenia i średni wiek wyborców

\begin{tabular}{|l|c|c|c|c|}
\hline \multicolumn{1}{|c|}{ I tura } & Liczebność & Procent & Średni wiek & $\begin{array}{c}\text { Wskaźnik } \\
\text { wykształcenia }\end{array}$ \\
\hline Dla całej próbki & 2072 & 100,0 & 45 lat & 3,40 \\
\hline T. Dziuba (PiS) & 375 & 18,1 & 49,9 lat & 3,32 \\
\hline B. Grobelny (niez.) & 26 & 1,3 & 48,9 lat & 2,92 \\
\hline R. Grobelny (były prezydent ) & 600 & 29,0 & 45,8 lat & 3,40 \\
\hline
\end{tabular}




\begin{tabular}{|l|r|r|r|c|}
\hline \multicolumn{1}{|c|}{ I tura } & Liczebność & Procent & Średni wiek & $\begin{array}{c}\text { Wskaźnik } \\
\text { wykształcenia }\end{array}$ \\
\hline J. Jaśkowiak (PO) & 442 & 21,3 & 45,2 lat & 3,48 \\
\hline Z. Kopacz (NP) & 85 & 4,1 & 32,5 lat & 3,36 \\
\hline T. Lewandowski (SLD) & 366 & 17,7 & 42,6 lat & 3,35 \\
\hline A. Wachowska (RM) & 97 & 4,7 & 41,6 lat & 3,59 \\
\hline M. Wudarski (RM) & 71 & 3,4 & 40,6 lat & 3,62 \\
\hline Ogółem & 2072 & 100,0 & & \\
\hline
\end{tabular}

\begin{tabular}{|l|c|c|c|c|}
\hline \multicolumn{1}{|c|}{ II tura } & Liczebność & Procent & Średni wiek & $\begin{array}{c}\text { Wskaźnik } \\
\text { wykształcenia }\end{array}$ \\
\hline R. Grobelny & 701 & 40,5 & 49,1 & 3,25 \\
\hline J. Jaśkowiak & 1032 & 59,5 & 46,0 & 3,40 \\
\hline Ogółem & 1733 & 100,0 & 100,0 & \\
\hline
\end{tabular}

Źródło: opracowanie własne na podstawie danych exit poll.

Można też dostrzec, że znacznie częściej wyborcy PiS byli skłonni głosować w drugiej turze na konserwatywnie usposobionego i otwarcie manifestującego swoje przywiązanie do katolicyzmu oraz bliskie relacje z kościołem instytucjonalnym Ryszarda Grobelnego (dotychczasowego prezydenta) niż kandydata opozycji. W przypadku Jacka Jaśkowiaka (obecnego prezydenta) poparcie dla niego częściej deklarowały osoby, które w pierwszej turze głosowały na SLD i na przedstawicieli ruchów miejskich. Grupie zwolenników kandydatów ruchów miejskich bliżej było zatem do przekazu lewicowego i centrowego, w opozycji do publiczności bardziej jednoznacznie konserwatywnej.

TABELA 2. „Przepływy elektoratów” w drugiej turze wyborów prezydenckich w Poznaniu w 2014 roku na podstawie exit poll

\begin{tabular}{|l|c|c|c|c|}
\hline $\begin{array}{c}\text { II tura, } \\
\text { przepływy } \\
\text { elektoratów }\end{array}$ & $\begin{array}{c}\text { Liczebność } \\
\text { (głosujących } \\
\text { na Ryszarda } \\
\text { Grobelnego) }\end{array}$ & $\begin{array}{c}\text { Procent } \\
\text { (głosujących } \\
\text { na Ryszarda } \\
\text { Grobelnego) }\end{array}$ & $\begin{array}{c}\text { Liczebność } \\
\text { (głosujących } \\
\text { na Jacka } \\
\text { Jaśkowiaka) }\end{array}$ & $\begin{array}{c}\text { Procent } \\
\text { (głosujacych } \\
\text { na Jacka } \\
\text { Jaśkowiaka) }\end{array}$ \\
\hline Braki danych & 54 & 7,7 & 78 & 7,6 \\
\hline T. Dziuba & 137 & 19,5 & 50 & 4,8 \\
\hline B. Grobelny & 13 & 1,9 & 10 & 1,0 \\
\hline R. Grobelny & 387 & 55,2 & 86 & 8,3 \\
\hline J. Jaśkowiak & 26 & 3,7 & 503 & 48,8 \\
\hline
\end{tabular}




\begin{tabular}{|l|c|c|c|c|}
\hline $\begin{array}{c}\text { II tura, } \\
\text { przepływy } \\
\text { elektoratów }\end{array}$ & $\begin{array}{c}\text { Liczebność } \\
\text { (głosujących } \\
\text { na Ryszarda } \\
\text { Grobelnego) }\end{array}$ & $\begin{array}{c}\text { Procent } \\
\text { (głosujących } \\
\text { na Ryszarda } \\
\text { Grobelnego) }\end{array}$ & $\begin{array}{c}\text { Liczebność } \\
\text { (głosujących } \\
\text { na Jacka } \\
\text { Jaśkowiaka) }\end{array}$ & $\begin{array}{c}\text { Procent } \\
\text { (głosujących } \\
\text { na Jacka } \\
\text { Jaśkowiaka) }\end{array}$ \\
\hline Z. Kopacz & 12 & 1,7 & 14 & 1,4 \\
\hline T. Lewandowski & 34 & 4,9 & 153 & 14,8 \\
\hline A. Wachowska & 14 & 2,0 & 52 & 5,0 \\
\hline M. Wudarski & 7 & 1,0 & 31 & 3,0 \\
\hline $\begin{array}{l}\text { nie głosował } \\
\text { w I turze turze }\end{array}$ & 17 & 2,4 & 54 & 5,3 \\
\hline Ogółem & 701 & 100,0 & 1031 & 100 \\
\hline
\end{tabular}

Źródło: opracowanie własne na podstawie danych exit poll.

Na podstawie przywołanego badania, a także wyników wyborów do rady miasta z 2010 (przypomnijmy, że Stowarzyszenie My-Poznaniacy zdobyło wtedy 9,32\%) i 2014 roku można oszacować liczebność publiczności, przede wszystkim „nowomieszczańskich”, ruchów miejskich w Poznaniu na ok. 10-15\% poznaniaków ${ }^{18}$. Pozwala to pisać o zwolennikach „opcji miejskiej” w kategoriach zbiorowości mniejszościowej, której pozycja wydaje się silniejsza, niż wynikałoby to jedynie ze statystyk wyborczych. W konsekwencji, po kilku latach przełożyło się to np. na zaistnienie jednoosobowego klubu w Radzie Miasta Poznania, obsadzenie stanowiska wiceprezydenta kandydatem ruchów miejskich (został nim M. Wudarski), a także zajęcie kilku istotnych pozycji urzędniczych przez członków stowarzyszeń miejskich. Zasugerowane liczebności oraz funkcja języczka u wagi nie są właściwe jedynie dla sytuacji poznańskiej, podobne obserwacje można poczynić na podstawie danych dotyczących Warszawy czy kilku mniejszych miast (można przywołać po raz wtóry przykład Gorzowa Wielkopolskiego).

18 Zupełnie inną, zdecydowanie mniej liczną, nie mniej istotną jednak w kontekście kapitału symbolicznego publiczność wytwarza i posiada lokalny ruch (neo)anarchistyczny i lokatorski. Dla dopełnienia obrazu trzeba zatem wskazać na istotną rolę środowisk (neo)anarchistycznych, aktywnych w polu polityk miejskich oraz wytwarzaniu lokalnej sfery kontrpublicznej, związanych przede wszystkim ze słotami „Rozbrat”, „Od:zysk” oraz klubokawiarnią „Zemsta”, częściowo zaś również „Wielkopolskim Stowarzyszeniem Lokatorów”. Publiczność tę jednak trudno oszacować liczbowo, w każdym razie nie za pomocą narzędzi z jakich korzystamy. 


\section{PODSUMOWANIE}

Pojęcie e pluribus unum ilustruje intrygującą synergię ewolucji miejskiej aktywności, która przebiegała wielotorowo, przybierając - po 25 latach od zmiany systemu - kształt wewnętrznie zróżnicowanego ruchu. Zaproponowane w tym artykule wnioskowanie sugeruje obecność kontrapunktu, nawiązań zarówno do neoanarchistycznego radykalizmu, jak i historycznego doświadczenia ,pospolitego ruszenia" komitetów obywatelskich i następstw społecznych karnawału „Solidarności”.

Przynajmniej na początku (w latach 2010-2011) obydwa kontrapunkty wydawały się katalizować siebie na wzajem. W konsekwencji relatywnego sukcesu, będącego konsekwencją kohabitacji z systemem jednego z nich, zjawisko synergii wyraźnie osłabło. Nie zmienia to faktu, że mamy do czynienia z wyłonieniem się we współczesnym środkowoeuropejskim mieście fenomenu społecznego stanowiącego forpocztę zmian typu podmiotowości mieszkanek i mieszkańców. Zmiana ta w odróżnieniu od logiki transformacji systemowej jest endogenna, choć odpowiada na uniwersalne, egzogenne tendencje wpisane w zmiany postnowoczesnego miasta.

\section{BIBLIOGRAFIA}

„Homek”. Pismo Ruchu Spoleczeństwa Alternatywnego 1983-1990. G. Berendt, K. Brzechczyn, Z. Stybel, J. Waluszko (red.). Gdańsk: Instytut Pamięci Narodowej.

Antonów Radosław. 2004. Pod czarnym sztandarem. Anarchizm w Polsce po 1980 roku. Wrocław: Wydawnictwo Uniwersytetu Wrocławskiego.

Aslund Anders. 2010. Jak budowano kapitalizm. Transformacja Europy Środkowej i Wschodniej, Rosji i Azji Środkowej. Warszawa: Książka i Wiedza/FOR.

Błaszczyk Mateusz. 2013. W poszukiwaniu socjologicznej teorii rozwoju miast. Meandry ekonomii politycznej. Warszawa: Wydawnictwo Naukowe SCHOLAR

Brenner Neil, Peck Jamie, Theodore Nik. 2010. „After neoliberalization?”. Globalizations. September 7(3): 327-345.

Brenner Neil, Theodore Nik. 2002. "Cities and the geographies of "Actually Existing Neoliberalism"'. Antipode 34(3): 349-379.

Ciszewski Piotr. 2008/2009. „Obrońcy praw lokatorów”. Przegląd Anarchistyczny 8: 77-82.

Drozdowski Rafal. 2011. Lepsza sfera publiczna - bezdyskusyjny postulat pod dyskusję. W: O miejskiej sferze publicznej. Obywatelskość i konflikty o przestrzeń, M. Nowak, P. Pluciński (red.), 117-127. Kraków: ha!art.

Dunn Elisabeth. 2008. Prywatyzując Polskę. O bobofrutach, wielkim biznesie i restrukturyzacji pracy. Warszawa: Wydawnictwo Krytyki Politycznej.

Frączak Pawel. 2010. „Wybrane uwarunkowania występowania syndromu NIMBY”. Nierówności Spoteczne a Wzrost Gospodarczy 17: 314-324. 
Górski Rafal. 2007. Bez państwa. Demokracja uczestniczaca w działaniu. Kraków: ha!art.

Harvey David. 2012. Bunt miast. Prawo do miasta i miejska rewolucja. Warszawa: Fundacja Nowej Kultury Bęc Zmiana.

Jacobsson Kerstin. (red.). 2015. Urban Grassroots Movements in Central and Eastern Europe. Farnham-Burlington: Ashgate.

Jacobsson Kerstin. 2013. Entrepreneurial Poland: On civic privatism in Polish civil society. http://www.detcivilasamhallet.se/pages/dokument/jacobsson_entrepreneurial_poland.pdf.

Kowalik Tadeusz. 2009. www.polskatransformacja.pl. Warszawa: Wydawnictwo Literackie „Muza”.

Kubicki Pawel. 2016. Wynajdywanie miejskości. Polska kwestia miejska z perspektywy dtugiego trwania. Kraków: Zakład Wydawniczy NOMOS.

Lefebvre Henri. 2012. „Prawo do miasta”. Praktyka Teoretyczna 5.

B1996. Społeczne uwarunkowania eliminacji syndromu NIMBY. W: Podmiotowość społeczności lokalnej, R. Cichocki. (red.), 295-308. Poznań: Media G.T.

Mergler Lech. 2008. Poznań konfliktów. Poznań: Stowarzyszenie „Lepszy Świat”.

Mergler Lech. 2014. O ruchach miejskich, czyli dla kogo jest miasto?. W: Miasto na żąanie. Aktywizm, polityki miejskie, doświadczenia, Ł. Bukowiecki, M. Obarska, X. Stańczyk (red.), 89-93. Warszawa: Wydawnictwo Uniwersytetu Warszawskiego.

Mergler Lech, Pobłocki Kacper. 2010. „Nic o nas bez nas: polityka skali a demokracja miejska". ResPublica Nowa 11-12.

Mergler Lech, Pobłocki Kacper, Wudarski Maciej. 2013. Antybezradnik perzestrzenny. Prawo do miasta $w$ działaniu. Warszawa: Respublica Nowa.

Merrifield Andy. 2002. Metromarxism. A Marxist Tale of the City. New York-London: Routledge.

Nawratek Krzysztof. 2008. Miasto jako idea polityczna. Kraków: ha!art.

Nowak Marek. 2007. „,Modele rewolucji” Hannah Arendt a „rewolucja Solidarności”. Próba interpretacji dyskursu po 25 latach. W: O rewolucji. Obrazy radykalnej zmiany społecznej, K. Brzechczyn, M. Nowak (red.), 237-257. Poznań: Wydawnictwo IF

Nowak Marek. 2015. Teoria nieracjonalnego działania. Socjologiczne studium na temat wolontariatu i społecznego aktywizmu. Poznań: Wydawnictwo Naukowe UAM.

Nowak Marek. Środkowoeuropejski 'ruch miejski' jako ruch społeczny środkowych segmentów struktury społecznej AD 2014. W: O kulturze protestu jako rdzeniu tradycji europejskiej, P. Żuk (red.), 17-62. Warszawa: Wydawnictwo Książka i Prasa.

Ost David. 2005. Klęska „, Solidarności”. Gniew i polityka w postkomunistycznej Europie. Warszawa: MUZA SA.

Partycypacja. Przewodnik Krytyki Politycznej. 2012. J. Erbel, P. Sadura (red.). Warszawa: Wydawnictwo Krytyki Politycznej.

Piotrowski Grzegorz, Dominika V. Polanska. 2015. „The transformative power of cooperation between social movements: Squatting and tenants' movements in Poland". City 19(2-3).

Pluciński Przemysław. 2012. „Metroengelsizm, czyli o Engelsowskich korzeniach krytycznych badań nad miastem". Nowa Krytyka 28.

Pluciński Przemysław. 2013. „Miejskie (r)ewolucje. Radykalizm retoryki a praktyka reformy”. Praktyka Teoretyczna 3.

Pluciński Przemyslaw. 2014. „Miasto to nie firma! dylematy i tożsamość polityczna miejskich ruchów społecznych we współczesnej Polsce”. Przeglą Socjologiczny 1.

Pluciński Przemysław. 2016. „Jaka demokracja miejska? Przypadek Ruchu Społeczeństwa Alternatywnego". Nowa Krytyka 36. 
Pluciński Przemysław. 2017. Od globalnego do lokalnego (i z powrotem). Miejskie ruchy społeczne i organizacje obywatelskie w Poznaniu w latach 2000-2015. W: Poznań w działaniu. Społeczne inicjatywy dawniej i dziś, M. Praczyk (red.), 89-115. Poznań: Stowarzyszenie Czasu Kultury.

Pobłocki Kacper. 2014. Kijem w szprychy. W: My i oni. Przestrzenie wspólne / projektowanie dla wspólnoty, 91-100. Warszawa: Fundacja Nowej Kultury Bęc Zmiana.

Pobłocki Kacper. 2014. Nowa dekada, nowe miasto? W: Miasto na żadanie. Aktywizm, polityki miejskie, doświadczenia, Ł. Bukowiecki, M. Obarska, X. Stańczyk (red.), 53-61. Warszawa: Wydawnictwo Uniwersytetu Warszawskiego

Purcell Mark. 2008. Recapturing democracy. Neoliberalization and the struggle for alternative urban futures. Routledge: New York-London.

Słodkowska Inka. 2014. Komitety obywatelskie 1989-1992. Rdzeń polskiej transformacji. Warszawa: Instytut Studiów Politycznych PAN.

Smith Neil. 2010. Uneven development: Nature, capital and the production of space. London 2010.

Tezy o mieście. 2011. W: Coś, które nadchodzi. Architektura XXI wieku, 326-327. Warszawa: Fundacja Nowej Kultury Bęc Zmiana.

Urbański Jarosław. 2002. Globalizacja a konflikty lokalne. Poznań: 2002 [uwaga: książka ta funkcjonuje niekiedy pod tytułem Globalizacja a konflikty społeczne, co jest efektem błędnego wydruku tytułu na okładce].

Warszawskie Stowarzyszenie Lokatorów. Wywiad z działaczami. 2008/2009. Przegląd Anarchistyczny 8.

Przemystaw Pluciński

Marek Nowak

\title{
E PLURIBUS UNUM? SOURCES AND SPECIFICITIES OF URBAN MOVEMENTS IN CONTEMPORARY POLAND
}

\begin{abstract}
This article focuses on two threads: identification and interpretation of the sources of urban social movements in Poland, and an attempt to diagnose the phenomenon. Ideological tensions are shown to be present within the various strands of urban activism, to a varying degree seeking identity in connection with the traditional "right to the city". We also look for synergy, a peculiar "unity in diversity" arising out of the conditions of a modern Central European city. The final part of the text consists of a quantitative analysis and an attempt to characterize urban movements, using Poznań as an example. The data sources used were exit polls and data from the National Electoral Commission.

Keywords: the right to the city, urban social movements, neo-anarchist movement, origins of urban social movements
\end{abstract}

